\title{
Learning of Catholic theology in the digital age
}

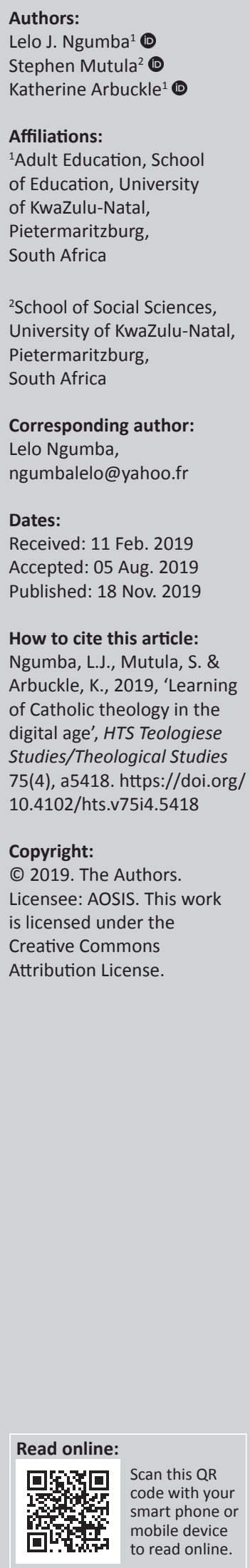

This article focuses on the intersections between theological knowledge and the use of the Internet to access study resources for students studying Catholic theology at tertiary institutions. In the 21st century, the use of the Internet to access electronic resources (ERs) is gaining momentum as a tool for obtaining needed information among theology students, to support many aspects of their learning activities. This is mainly because of the proliferation of online theological libraries, as well as the fact that theology students ought to resist the easy path of uncritical passivity and select reliable data from other resources, and welcome it without merely imposing their critical theological opinions and views. Recent literature indicates that the hierarchical nature of Catholic doctrine needs not to exclude openness to the more rhizomatic approaches to knowledge structures that students' independent accessing of online ER represents. This intersection in learning theology requires a theoretical paradigm shift for adult theology students which can contribute greatly to the enlargement of the theology students' academic horizon and enriches their minds for an open theological dialogue and discussion with different theological opinions and views.

Keywords: electronic resources; learning; theology students; tertiary education; Catholic theology.

\section{Introduction}

In the early 1960s, when the Internet started in the US Army as an information and communication network, nobody thought and expected that it would have such a great impact on the learning process as it does today. During the early 1990s, the Internet gained momentum as a public network (Rasha 2007). Since then, the use of the Internet has led to tremendous changes in many areas of daily life, especially in the field of education. The use of the Internet in the field of education has increased exponentially because of the availability of electronic resources (ERs) for learning. Electronic resources refer to any materials that require Internet access (Renwick 2005). Some of the most frequently encountered ERs include e-journals, e-books and full-text databases, and YouTube clips. Students have the option of using both traditional resources, such as physical textbooks and physical libraries, and ERs in their studies. Electronic resources have become a vital and integral part of libraries for learners of all ages (McGloughlin \& Lee 2010; Smith, Salaway \& Caruso 2009) where they can find information without necessarily having to physically visit a library.

In this rapidly changing digital society, students, particularly Catholic theology students, have grasped the potential of ER as a research centre in their learning activities (Campbell 2013). Internet-based ERs offer a wide range of information to support for informal or formal learning activities. Access to this variety of information has brought about a change in the way that theological knowledge is constructed (Soukup 2014). As a consequence, students in the contemporary world are likely to encounter a range of information choices (Campbell 2012) between Catholic and non-Catholic teachings in their learning activities. In addition, the Catholic environment of learning of theology by adult students provides a conflicted arena for the use of different teachings from both 'sides'.

In a modest way, Gr Grocholewski (2014) (prefect of the Congregation for Catholic Education), reflecting on the current and future educational challenges of learning theology in the 21st century, pointed out that Catholic researchers, and especially students, are facing dilemmas with regard to accessing ER, especially those materials that have not been vetted by the Catholic Church. He also wanted to interrogate the kinds of information they sought and retrieved, a concern previously mentioned by others (Dabbagh \& Kitsantas 2011; November 2010). He was concerned about the existence of the variety of divergent views expressed in the wide range of ER. As stated by Campbell (2012), those divergent views challenged and freed the learning of Catholic theology from the traditional structures. Thus, some of the emerging theology materials or information, obtained electronically, have moved towards their own theological reflection on the praxis of 
Christian faith rather than embracing the Western theological reflection of traditional approaches. These new developments of theologies are creating new challenges which push theologians and theology students against the strict boundaries of traditional theology where they can undermine authorities and control (Diez Bosch et al. 2017).

The quest in this article is to understand such problematic in the learning of Catholic theology by adult students at the present time, that is, how to learn Catholic theology with the use of ER. This review brings learning and Catholic theology into dialogue with the use of ER in learning processes generally, to explore learning implications and challenges that emerge for teaching and learning Catholic theology in the 21st century. To inquire into the literature related to this current review, the following outlook is taken.

This article begins with the need for exploring the changing attitudes in official Catholic position towards ER. Secondly, it explores the perceived challenges for the Catholic Magisterium at the present time of making use of ER in circulation through the Internet. Thirdly, it also interrogates the use of ERs in the learning of theology. This section outlines learning implications that emerge from using the Internet to access ER in learning theology, and the impact of the revolution of ER in learning theology.

\section{Changing attitudes in official Catholic position towards electronic resources}

Over the past 35 years, the idea of the use of the Internet to access ER has attracted great interest on the part of many scholars specialising in the learning of theology in higher education (Campbell 2013; Campbell \& Garner 2016; Soukup 2014). The emerging literature in relation to theology and the Internet have been providing a clear overview of how theology can be negotiated and renegotiated in the digital culture (Soukup 2014). Since the 1990s, the use of the Internet has been considered by the Catholic Church as a tool to access new spiritual and religious information. Consequently, Catholic magisterial authorities have been debating, reflecting and exploring the issues relating to the Internet and its positive features for the teaching and learning of theology and for the mission of the church. Stuart-Buttle (2013) understands magisterium as a teacher (pontiff and bishops) whose role is to describe the official teaching of Catholic faith with regard to the doctrine.

In 2002, two fundamental documents were published by the Foley (2002a and 2002b) in this regard: 'Ethics in the Internet' and 'The Church and the Internet'. These two documents invited all Catholic Christians to develop their ability to think critically when they make use of the Internet to access ER with regard to specific doctrinal materials. The rationale of using ER is that it provides opportunities for cultivating the ability to think and the potential for reflection by learners. The two documents also envisaged that the use of
ER can 'contribute greatly to the enlargement and enrichment of men's minds' (Foley 2002a:5), and can serve as a supplement to traditional means of instruction for learners. Furthermore, the use of ER changes not only how students learn things but also how they understand their subjects (Foley 2002b).

These two documents assert that the use of ER facilitates a learner-centred and a more personalised approach to learning while meeting the learner's needs. Therefore, with these two documents, the Catholic Church aims to help learners to access ER appropriately for intellectual development.

The Catholic Church acknowledges that the use of ER can provide opportunities for scholars and learners to find out about and get in touch with different theological views. This makes it possible for theologians and theology students to deepen a continuous relationship between religion and media as well as spirituality and community (Campbell 2011; 2012; Diez Bosch 2015; Spadaro 2016); to shape our understanding of religious practice as well as how faith is negotiated within digital culture (Campbell 2013, Campbell \& Garner 2016); to carefully consider what it means to teach theology in the digital age (Deberque \& Harrison 2015); even our notion of how authorities are defined in networked theology within new media worlds (Diez Bosch et al. 2017); to address the question of YouTube as a platform for communication, as well as getting greater understanding of the existent problematic and official attitude of the Catholic Magisterium with regard to the use of alternative theological contents (Soukup 2014). These factors make evident how theological reflection is changing in the contemporary context of negotiating and renegotiating faith in the digital age.

Bearing in mind the aforementioned development, it supports Stuart-Buttle (2013) that if the Catholic Church and its Magisterium want the studies of theology to take place in this modern world, it cannot ignore the use of ER made available in the subject of theology. In the same vein, Grocholewski (2014), the prefect of congregation for Catholic education, published a document Education today and tomorrow: A renewing passion. The document pointed out the need for promoting constant theological reflection which favours an open dialogue within and outside the Catholic Church. This theological reflection should strive to promote the use of ER for academic research and to foster critical thinking in self-directed learning in the light of the Catholic faith and teaching. It is important to acknowledge that, in the context of easy access of information, critical thinking favours a learner's reasoning and imagination for acquiring in-depth theological understanding and the abilities of learning how to learn (Grocholewski 2014). The Congregation for Catholic education highly encourages learners to foster their ability to think critically where the use of the Internet has increased access to ER. Its expectation is that learners should develop the skill of critical reading so as to be able to engage in constant dialogue with the 
theological information that is put in circulation electronically through the Internet. This means that learners should have the ability of analysing, evaluating, questioning and interpreting their content (Stuart-Buttle 2014). The use of ER, according to the same document, stimulates active learning and sparks theology students' curiosity which is different from passive learning (Grocholewski 2014). Electronic resources provide students with an opportunity for self-learning and self-improvement (Grocholewski 2014). In this regard, the use of ER could help theology students to strive for constant and ongoing theological learning to be opened to in-depth understanding of the theological content that is put in circulation through the Internet (Stuart-Buttle 2014).

In accepting the use of ER by theology students, the Catholic Church wanted to inculcate a passion for learning, rather than considering the learning process as an obligation or an imposition. When they become aware that what they are learning is for their intellectual development, they are likely to be more motivated, and learning will increase. Bearing in mind Grocholewski's reflection on the use of ER in theological learning, Stuart-Buttle (2014) points out that because of the use of ER, theological learning has grown in recognition and respect for diversity. This diversity of theological views should not be suppressed, but should rather be considered as an opportunity for open dialogue. By the same token, Catholic theological learning should be more inclusive and open to diversity, accepted and appreciated as an educational challenge that could be beneficial to the learner in fostering a critical mind.

John Paul II in his pontificate strongly encouraged the use of the Internet. In 2001, John Paul II argued that the Catholic Church should not be considered as a mere spectator in the concerns of Internet advances which had a decisive impact on the people's daily lives. In his message of 2005, through the Pontifical Council for Social Communication, John Paul II asserted that the use of the Internet was an integral part of the Church's mission and provided resourceful information for learning in the third millennium. At the same time, John Paul II invited people to use the Internet wisely.

The call for the use of technologies especially the Internet with critical awareness, as stated by the Vatican II Council, was taken seriously by Benedict XVI. In his message for the 43rd World Day of Communication in 2009, he called on everybody to promote and practise a 'culture of respect, dialogue and friendship' (Paragraph 1) in communicating the truths of the faith when using the Internet. He affirms that the Internet allows students and researchers to access information and search for the truth. At the same time, it has opened an opportunity for dialogue that can facilitate more dynamic forms of knowing other theological traditions and values (Paragraph 2). For Benedict XVI, this dialogue:

[...M] ust be rooted in a genuine and mutual searching for what God wants to communicate to the humanity if it is to realize its potential to promote growth in understanding and tolerance. Life is not just a succession of events or experiences: it is a search for the true, the good and the beautiful. It is to this end that we make our choices; it is for this that we exercise our freedom; it is in this - in truth, in goodness, and in beauty - that we find happiness and joy. (Paragraph 6)

Furthermore, Benedict XVI was aware of the challenges that the Internet was bringing to people's growth in faith and Christian learning. He stated:

$[I] \mathrm{t}$ is important to focus not just on their undoubted capacity to foster contact between people, but on the quality of the content that is put into circulation using these means. (Paragraph 4)

In 2010, on the occasion of the message for the 44th World Day of Communication, he underlined that the Internet could open up wide new views for dialogue and the learning process. He asserted that the Internet:

$[\ldots B]$ rings us into contact with the followers of other religions, non-believers and people of every culture, requires sensitivity to those who do not believe, the disheartened and those who have a deep, unarticulated desire for enduring truth and the absolute. (Paragraph 8)

Pope Francis embraces the same line as his predecessors John Paul II and Benedict XVI with regard to the use of ER in learning process. In June 2014, during his message for the 48th World Day of Communication, Pope Francis acknowledges the use of the Internet and how it offers immense possibilities for bringing information closer to learners; it makes and connects learners connected to information, and therefore helps in research and learning process (Paragraph 2). The pontiff suggested that in using ER, learners have opportunities of entering in dialogue with other theological views. He acknowledged that non-Catholics have something worthwhile to share with regard to the theological knowledge. Therefore, Catholic theologians should not be of the opinion that they only hold a monopoly of theological knowledge (Paragraph 3). For Pope Francis, the openness of the Catholic Church in welcoming different theological perspectives put in circulation electronically through the Internet might help theologians and theology students to begin to think more broadly and to value other theological knowledge and traditions. What can be seen from the Catholic Magisterium and messages of these three pontiffs (John Paul II, Benedict XVI and Francis) is that there has been, and continues to be, a growing interest in, and creative engagement with, the use of ER in the learning of theology. In other words, this shows how the Catholic Magisterium has moved from the simplistic frame of considering that the use of ER is either good or evil, towards the effort of understanding how it can shape students' minds. This changed stance also opens up the opportunity of understanding how it can foster new way of theological inquiring which might help students to contextualise and explain their faith in this modern and contemporary theological reflection (Campbell \& Garner 2016). 


\section{Perceived challenges for the Catholic Magisterium}

Catholic Magisterium openness to the use of ER reflects somewhat ambiguous attitudes. On the one side, it is seen as a tool for a constant negotiation between the sources (tradition and doctrine) and the seeking of understanding and intelligent action in the contemporary context of the world. This vision likely empowers researchers and students in theology with new and relevant understanding for contextualising theology. On the other side, it is quite pessimistic with regard to new authoritative voices appearing from ERs which can silence and oppress the traditional one (Campbell \& Garner 2016). This included, for instance, the progressive secularisation culture which introduced selective and optional choices. These create a fear for the relocation of the authority structures and the changing of how faith, doctrine and tradition might be understood (Diez Bosch et al. 2017).

These ambiguous attitudes begin to surface the key concerns for the Catholic Magisterium with regard to a growing literature that emerged from different backgrounds that can challenge and undermine aspects (Campbell 2013) of Catholic traditional structures. According to Campbell and Garner (2016), these ambiguous attitudes with regard to the use of ER rather than hierarchical structures of theological knowledge can promote flattened one which can create tensions and anxiety when the traditional structures (tradition and doctrine) are undermined (Campbell \& Garner 2016). It can be said that such attitudes might raise a core question of the nuanced and the established authorities. In the same vein, Pope Francis, writing for the 48th World Day of Social Communications (2014), highlighted how the use of Internet ER shapes scholars' and students' understandings of authorities. He argued:

The speed with which information is communicated exceeds our capacity for reflection and judgement, and this does not make for more balanced and proper forms of self-expression. The variety of opinions being aired can be seen as helpful, but it also enables people to barricade themselves behind sources of information which only confirm their own wishes and ideas. (Paragraph 3)

Pope Francis' thought is similar to that of Stuart-Buttle (2014), who was reflecting and writing from the UK theological perspective, and underlined the issue of what it means to do theology as well as to be theologians in the digital age. She pointed out that (Stuart-Buttle 2014):

In recent times, theologians and educators have sought to invite dialogue with the postmodern world in order to bring the Christian narrative into the contemporary context. The idea of continuity holds that Christian faith must be in dialogue with contemporary culture and society in order to bridge or open new possibilities for Christian expression. However, critics hold a different reading of the Christian narrative, seeing discontinuity or rupture between faith and a secularized, pluralist, and detraditionalized contemporary world. Such critique limits the possibilities of reciprocal dialogue by closing off Christian faith and tradition. (p. 67)
The current diverse or comprehensive theological contents from ER surprise the traditional governed doctrine and the regulation of or by the new authority figures who sometimes may differ from the official doctrine which deconstruct the hierarchical teaching and learning of the Catholic theology. According to Campbell (2012), this tension of authorities raised the real problem between renegotiation and canonisation of the accepted sources.

Benedict XVI (2009) had already noticed this problem and argued that some theological materials or information from ER had taken theological knowledge and interpretation away from authoritative sources.

He further argued that their authors were influenced by modern-day culture and that they combined this influence with religious concepts and then presented their theological information as if they were conforming to Christian doctrine and faith. Such theological reflections must accept that the active process of dialogue with other theological views should be flexible and open to negotiate knowledge and to contextualise theological reflection within an emergent secularised culture (Campbell \& Garner 2016). According to Boeve (2009), this theological assumption invites all theologians to open up the dynamic praxis in which theological reflections on Christian doctrine and faith can be re-articulated while simultaneously respecting other theological worldviews. The real impact of the use of ER is disrupting the relationship between the authorities with the principles of interpretation and meaning making underlined by Catholic doctrine and teaching (Stuart-Buttle 2013). In addition to that, for Campbell (2013), the impact of using ER in learning theology currently creates a paradox regarding traditional authority by decentralising the space of hierarchical control. It also creates the complexity of how traditional structures of authority may need to renegotiate with the new authorities. Such attitude raised the key concern of the hierarchical control in which a believer and learner cannot reflect freely on theological matters without the doctrinal limitations of faith.

The studies conducted by Sajjadi (2008, 2009 and 2014) on theological learning within the digital age revealed that a rhizomatic approach to knowledge (Deleuze \& Guattari 1987) may offer new ways of understanding how knowledge is constructed in the 21st century within the ERs. Deleuze and Guattari (1987) developed from a botanical perspective a new theoretical approach for understanding how knowledge is constructed which emphasises the horizontal structuring of knowledge. Deleuze and Guattari (1987) offered a new alternative for understanding the interconnectedness of knowledge construction. They pointed out the distinction between the 'arborescent' and 'rhizomatic' structures of knowledge, emphasising the weakness of the hierarchical and dichotomous nature of the arborescent structure. Deleuze and Guattari (1987) outlined six principles within the rhizome. The first and second principles are 
connection and heterogeneity. The third and fourth principles are multiplicity and assigning rupture. Lastly, the fifth and sixth principles are cartography and decalcomania. So, in using multiple sources in learning theology, learners break the traditional theological discipline and they open new communication with other worldviews of theological knowledge.

According to the above discussion, the use of ER ought to play an important role for the learning of theology in the 21st century and to set a new horizon for Catholic Magisterium to shape its way of negotiating and contextualising its theological knowledge. Catholic theology is confronted with challenges of 'principles, methods, and content that could be addressed by advances in information technology and the creation of new structure of knowledge' (Sajjadi 2008:189). It is likely that the openness of the Catholic Magisterium in accepting the academic freedom and rigour in interpreting theological knowledge might help theology students to understand their intellectual development within the Christian tradition and doctrine. For Conway (2011), this does not mean that the academic freedom of interpretation and rigour with regard to the theological knowledge obtained electronically through the Internet must inevitably compromise theological knowledge safeguarded by the Christian tradition and doctrine, instead it would enrich it. For this reason (Sajjadi 2008):

[... I]n rhizomatic space one must not expect a teacher to deliver predefined orders, discipline, and rules ascertained from religious texts. Deleuze denies such order and discipline for its emphasis on imitating and modelling. Discipline requires a person to follow a straight route that is logical and rational. (p. 188)

With the breaking of the traditional theological discipline and the emphasis on theological multi-sources, the rhizomatic approach to knowledge in the studies of theology can promote students' potential for theological personalised knowledge and learning. By weakening the hierarchical and linear theological discipline in which only a theological elite can interpret 'the truth of the faith' or the Christian doctrines (Benedict XVI 2009) and learners are unable or unqualified, rhizomatic approach to knowledge brings a learner to the level of co-creator of theological knowledge. The rhizomatic approach to knowledge facilitates a learner being actively involved in the process of making meaning and inventing ideas rather than mechanically accumulating ideas are given to him by the theological elite during the class setting. The Catholic Magisterium understands that in the current decade, theology students are making use of both printed copies and ER. Rather than waiting, Catholic Magisterium has to be proactive in shaping its approach to the learning of theology. This requires, for instance, more flexibility, easy access to information, critical thinking and innovative cooperation in teaching and learning of theology. The following section discusses how the integral use of ER changes the understanding of learning theology by adult students.

\section{The use of electronic resources in the learning of theology}

To have a better understanding of the use of ER in learning theology by adults, the concept of 'learning' is explained. One of the definitions that is relevant to this review comes from Herring (2010) who asserted that learning is the process of selecting and evaluating information to acquire knowledge and understanding. Herring pointed out that there are various ways of learning process such as cognitive, contemplative and dialectic, for example, learning as a simple acquisition of new information or as a reinterpretation and reintegration of new information to get an in-depth understanding. According to Pope John Paul II (1992), learning in the field of theology must be grounded in the 'contents of faith'. The contents of faith are God's revelation in Jesus Christ which is in communion with the Catholic Magisterium. For this reason, Pope John Paul II (1992) asserted that in learning, a theologian and a theology student should seek an ever in-depth knowledge of the divine mysteries to be able to explain to the world of today the reason for his or her faith and the Church's faith. What Pope John Paul II asserted long ago is still relevant for the learning of theology today. Thus, Pope John Paul II and the current Pope Francis' conviction is that an effective Catholic learning of theology should be performed purposively in the search for an understanding of the truths of the faith and the Catholic tradition. This means that theology students are encouraged to search for in-depth understanding of the truths of the faith in their learning processes.

According to Stuart-Buttle (2013), learning theology by adult students is viewed as the knowing and understanding of Christian doctrine and tradition within a critical search for deepening the understanding of the truths of the faith. This is significant to bear in mind, as this study considers learning by adult students in the intersection between learning of theology and the use of ER as a reflective and critical process. It is in the spirit of engaging to learn the contents of faith that Catholic process of learning theology shows signs of significant growth in using ER to enhance theology students' quality of theological knowledge, rather than its quantity. In the light of the aforementioned, Oliver (2014) argues that the core of learning theology by adult is not only about faith development but also to equip theologians and theology students with knowledge, skills and values that can be transferred to others to improve their lives.

\section{The revolution of electronic resources in learning theology}

Naidoo (2012), reflecting on the significant challenges in the formation of the theologian and his or her ministry in the current society, asserted:

For many years, theological institutions, particularly vocational ones, have acknowledged the need to keep an eye on what end product is required, asking what sort of person the churches need and designing programmes of study accordingly. (pp. 67-68) 
Previously, according to Banks (1999) and Kelsey (1993), learning theology was mainly focused on professional schooling by which learners could acquire specialised knowledge for the specific and successful mission of the Christian Church. In the last decade, critical questions have been raised on learning theology by adult students, for instance, 'about what is required for faithful teaching and learning and impact on the formation of the theological students' (Naidoo 2012:50). It is important to bear in mind that Naidoo is writing from the South African theological prospective. The critical questions raised by Naidoo (2012) have come from the growing recognition of the use of ER as a relevant tool for learning theology by adult students. Any debate concerning learning theology in connection with the use of Internet-based ER must flow from a sustained examination of the fundamental question about what ER means for learning theology by adult students. Alternative frameworks are needed for learning theology in this age of digital revolution (Stuart-Buttle 2013). Learning theology must therefore develop new learning strategies to increase students' understanding of their role as active co-creators of knowledge (Kirkwood \& Price 2014).

Jewell (2005) argued that, in order to stimulate positive learning outcomes, emphasis must be placed on how learning theology can facilitate learners to become inquisitive thinkers who reason, question and investigate.

The reason is that the ER revolution 'has made available a theological dialogue that has not been possible until this generation' (Jewell 2005:26). He suggested that learning theology may not be conventionally preparing students to 'equip the saints for the work of ministry' (p. 25), but 'turning to the immediate need' of most of the students which is deepening and reflecting upon their prior knowledge to reach new understandings. Similarly, Stuart-Buttle (2013) asks:

What sort of learning emerges, whether this is innovative or transformative, how it relates to existing interpretations of Christian education and faith formation, and what consequences it might hold for future adult faith ... (p. 29)

How would be the point in developing new learning strategies: the increasing of learning opportunities or critical prerequisite study? To meet this concern, scholars such as Naidoo (2012) argued that students must be actively involved in processing and searching for theological content to develop their knowledge. Mazur (2012) pointed out that when students learn their subjects through active and critical forms of searching and reflecting on the subjects presented, their motivation and engagement will be higher and the retention of subject matter will be greater. This expectation had already been raised by Bruner (1961) when he asserted that learning is not only a question of students acquiring information, but also learning how to process such information to get knowledge. He stated that to instruct a learner (Bruner 1961):

$[\ldots I] \mathrm{s}$ not a matter of getting him [sic] to commit results to mind. Rather, it is to teach him to participate in the process that makes possible the establishment of knowledge. We teach a subject not to produce little living librarians on that subject, but rather to get a student to think ... for himself [sic].... Knowing is a process, not a product. (p. 72)

What Bruner (1961) asserted long ago is still relevant for learning of theology today, in the context of making use of ER to supplement the learning process with relevant information. The effectiveness of the new learning strategies for learning Catholic theology by adult students will depend on its openness to the multi-directional connections of learning (Mazur 2012). Learning theology by adults in its new strategies should encourage, if not require, theology students to engage their learning processes in critical and reflective dialogue with prior research as a catalyst for their active learning. Obviously, the increasing interest in the use of ER for learning of theology has been considered as the fundamental reason for moving the theological learning focus towards a student-centred approach. Such a movement was predicted in the current decade by Stuart-Buttle (2013) and Naidoo (2012) who asserted that future theology students would be seeking learning which could be considered to be a more learner-centred approach. A learner-centred learning approach stimulates students' theological interest and curiosity to take the active role of co-creator of knowledge. Consequently, the role of theology teachers or lecturers must change to become more of a facilitator or mentor than a voice of authority. For instance, the theology teacher's task in a learner-centred approach is to help students to locate relevant theological information and then help them critically assess it (Naidoo 2012).

Learner-centred approach requires students to develop the ability to become self-directed. This means being able to take control of their learning process in being positively fostered in how to learn (Carre et al. 2011; Guglielmino 2013; Hiemstra 2011; John et al. 2009; Merriam, Caffarella \& Baumgartner 2007; Silvia \& Chin-Chung 2011; Song \& Hill 2007). In mastering their learning process, theology students must develop the awareness of their responsibility in planning their learning pace, carrying out learning comprehension and evaluating different aspects of their learning experience (Merriam et al. 2007). Being self-directed, theology students must understand their role as active co-creators of knowledge and teachers as facilitators of the process. However, according to Viktora (2005), some teachers have not been prepared to assume the role of facilitators in the learning process. He states (Viktora 2005):

Few of us had any extensive courses that focused on the pedagogical questions and issues we are now facing. Like many traditional educators who were classically trained, we fell into familiar and unreflective patterns for our teaching - either we taught the way we learned best or we taught the way we were taught. I have often heard the argument from colleagues in a discussion about examination of teaching styles that I survived the lecture format and learned the content, so it should be good enough for my students. (p. 41)

Theology students' familiarity and mastery of ERs obtained through the Internet can be seen as opening up new vistas 
and opportunities for building knowledge. Such new vistas and opportunities can be considered as challenges to traditional forms of knowledge building (Cormier 2008). According to Hughes (2005), self-directed learning enables theology students to develop new styles of learning with a capacity of analysing, synthesising and criticising scholarly information rather than merely memorising learning.

Barron (2006) argues that new horizons of learning with the help of ER do not come without challenges. One of the key challenges faced in the learning theology by adults is how to meet students' theological needs in a self-directed manner. LeMarquand and Galgalo (2004) presented students' needs that this review takes them as relevant. The pertinent question for some students is how best their theological studies can help them to be engaged in reflecting theology of development, peace, reconciliation and justice, ministry to the poor and in the context of HIV and AIDS. Generally, students' theological needs in self-directed learning are not the same as professors' theological needs; these two needs can sometimes clash. It is likely that these needs can 'be used as the backdrop for discussing theological beliefs and practices' (Simpson 2014:65). The focus must be on the students' theological needs. Whenever an idea does not appear sound, logical or comprehensive, theology students can be encouraged to reflect on what to do or how to think to propose learning theology to respond to adult students' needs. The role of learning theology should be just to suggest appropriate theological materials and resources to help theology students achieve their targeted theological needs (Simpson 2014).

\section{Conclusion}

The accessibility to the amount of information should be preceded by fostering students' understanding, which means to learn first to comprehend, and then to reason (Mercer \& Simpson 2015). Likewise, there can be a use that allows Catholic theology students to know more about other theological worldviews and to bring new theological contributions (Peterson 2015). Churchill and Churchill (2008) asserted that a better understanding of the importance of learning theology with the help of ER obtained through the Internet can create opportunities for learners' self-reflection, which is in dialogue with others theological worldviews.

Theological reflective activities can break linear and hierarchical teacher-student relationships (Sajjadi 2008), and open an appreciation of diversity for a healthy theological creative debate. Learners would be able to 'know their own starting points and embedded positions which, once recognized, could be challenged towards new or more meaningful theological frames of reference' (Stuart-Buttle 2014:63). The challenge for this creative theological debate is not only (Stuart-Buttle 2014):

[... T]o present Christian tradition in rich and stimulating curriculum frameworks. It is to invite attention to cultural, personal, and professional contexts in relation to church teaching and tradition. Authentic learning seeks engagement with Christian doctrine in fresh approaches that encourage a critical learning process to help shape one's personal interpretative map for meaning-making. (p. 64)

So, for this reason, learning theology by adults in the Catholic Church should involve theology students in a stronger commitment to produce more creative theological debate, which should be taken from any source or tradition. Learning theology in the context of the Catholic Church in using the ability of reflection must remain rooted in the truths of the faith revealed by God in Jesus Christ. In brief, accepting a creative theological debate means for Catholic learning of theology to learn from God who created us to be different. This is a sign that learning theology nowadays rather than being only dependent on the limited learning methods like in the past can be transformed in the place where important theological issues can be raised and discussed.

\section{Acknowledgements}

The author (L.J.N.) would like to thank Prof. Stephen Mutula (supervisor) and Dr Katherine Arbuckle (co-supervisor) for their contribution in building this article.

\section{Competing interests}

The authors have declared that no competing interests exist.

\section{Authors' contributions}

L.J.N. wrote this article. S.M. and K.A. helped through their guidance.

\section{Ethical consideration}

This article followed all ethical standards for a research without direct contact with human or animal subjects.

\section{Funding information}

This research received no specific grant from any funding agency in the public, commercial or not-for-profit sectors.

\section{Data availability statement}

Data sharing is not applicable to this article as no new data were created or analysed in this study.

\section{Disclaimer}

The views and opinions expressed in this article are those of the authors and do not necessarily reflect the official policy or position of any affiliated agency of the authors.

\section{References}

Banks, R., 1999, Re-envisioning theological education: Exploring a missional alternative to current models, William B. Eerdmans, Grand Rapids, MI.

Barron, B., 2006, 'Interest and self-sustained learning as catalysts of development: A learning ecology perspective', Human Development 49(4), 193-224. https://doi. org/10.1159/000094368 
Benedict XVI., 2009, New technologies, new relationships: Promoting a culture of respect, dialogue and friendship, Message for 43rd World Communications Day, viewed 19 November 2017, from https://w2 vatican.va/content/benedictxvi/en/ viewed 19 November 2017, from https://w2.vatican.va/content/benedictxvi/en/
messages/communications/documents/hf_ben-xvi_mes_20090124_43rd-worldmessages/communications/d
communications-day.html.

Boeve, L., 2009, 'The shortest definition of religion: Interruption', The Pastoral Review 5(4), 4-9.

Bruner, J.S., 1961, 'The act of discovery', Harvard Educational Review 31(1), 21-32.

Campbell, H.A., 2011, When religion meets new media, Routledge, London. https:// doi.org/10.4324/9780203695371

Campbell, H.A., 2012, 'Understanding the relationship between religion online and offline in a networked society', Journal of the American Academy of Religion $80(1)$ 64-93. https://doi.org/10.1093/jaarel/lfr074

Campbell, H.A., 2013, Digital religion: Understanding religious practice in new media worlds, Routledge, London.

Campbell, H.A. \& Garner, S., 2016, Networked theology: Negotiating faith in digital culture, Baker Academic, Grand Rapids, MI.

Carre, I., Jezegou, A., Kaplan, J., Cyrot, P. \& Denoyel, N., 2011, 'L'autoformation: The state of research on self-directed learning in France', International Journal of SelfDirected Learning 8(1), 7-28.

Churchill, D. \& Churchill, N., 2008. 'Educational affordances of PDAs: A study of a teacher's exploration of this technology', Computers \& Education 50(4) 1439-1450.

Conway, E., 2011, 'The future of Catholic higher education in Ireland', International Studies in Catholic Education 3(2), 158-169. https://doi.org/10.1080/19422539. 2011.603602

Cormier, D., 2008, 'Rhizomatic education: Community as curriculum', Innovate: Journal of Online Education 4(5), 20-35.

Dabbagh, N. \& Kitsantas, A., 2011, 'Personal learning environments, social media, and self-regulated learning: A natural formula for connecting formal and informa learning', Internet and Higher Education 15(1), 3-8. https://doi.org/10.1016/j. iheduc.2011.06.002

Deberque, Y. \& Harrison, J.R., 2015, Teaching theology in a technological age, Cambridge Scholars, Newcastle upon Tyne.

Deleuze, G. \& Guattari, F., 1987, A thousand plateaus: Capitalism and schizophrenia University of Minnesota Press, Minneapolis, MN.

Díez Bosch, M., 2015, 'Christianity as media history', Trípodos 37, 194-195.

Díez Bosch, M., Soukup, P., Micó Sanz, J.L. \& Zsupan-Jerome, D. (eds.), 2017, Authority and leadership: Values, religion, media, Ramon Llull University, Barcelona.

Foley, J.P., 2002a, Ethics in Internet. Pontifical Council for Social Communications, viewed 20 March 2017, from https://www.vatican.va/roman curia/pontifical councils/pccs/documents/rc_pc_pccs_doc_20020228_ethics-internet_en.html.

Foley, J.P., 2002b, The church and Internet. Pontifical Council for Social Communications, viewed 20 March 2017, from https://www.vatican.va/roman curia/pontifical councils/pccs/documents/rc_pc_pccs_doc_20020228_church-internet_en.html.

Francis, 2014, Communication at the service of an authentic culture of encounter Message for the 48th World Communication Day, viewed 15 May 2017, from https://w2 vatican va/content/francesco/en/messages/communications/ documents/papa-francesco_20140124_messaggio-comunicazioni-sociali.html.

Grocholewski, Z., 2014, Education today and tomorrow: A renewing passion Congregation for Catholic Education, viewed 10 June 2016, from https:// www.vatican.va/roman curia/congregations/ccatheduc/documents/rc con ccatheduc_doc_20140407_educare-oggi-e-domani_en.html.

Guglielmino, L.M., 2013, 'The case for promoting self-directed learning in formal educational institutions', SA-eDUC Journal 10(2), 1-18.

Herring, J.E., 2010, 'School students, information retrieval and transfer', Library and Information Research 34, 107-115, viewed 20 March 2016, from https://doi. org/10.29173/Lirg242.

Hiemstra, R., 2011, 'Self-directed learning: Individualizing instruction - Most still do it wrong', International Journal of Self-Directed Learning 8(1), 46-59.

Hughes, H., 2005, 'Action and reaction: Exploring international students' use of online information resources', Australian Academic and Research Libraries 36(4), 169179. https://doi.org/10.1080/00048623.2005.10755308

Jewell, J.P., 2005, 'What does all this technology mean for the church?', Theological Education 4(1), 17-29.

John Paul II., 1992, Post-synodal apostolic exhortation. Pastores Dabo Vobis, Vatican Editor, City of Vatican.

John Paul II., 2001, Apostolic letter, Novo Millennio Inuente, Catholic Truth Society, London.
John Paul II., 2005, The rapid development, Apostolic letter to those responsible for communications, viewed 17 October 2016, from https://w2 vatican.va/content/ john-paul-ii/en/apost_letters/2005/documents/hf_jp-ii_apl_20050124_il-rapidojohn-paul-ii/en
sviluppo.html.

John, W.L., Jacob, J.L., Soo-Hee, P., Lucy, W.G. \& Ryan, S., 2009, 'An investigation of the construct validity of the personality trait of self-directed learning', Learn Individ Differ 19(4), 411-418. https://doi.org/10.1016/j.lindif.2009.03.001

Kelsey, D.H., 1993, Between Athens and Berlin: The theological education debate, William B. Eerdmans, Grand Rapids, MI.

Kirkwood, A. \& Price, L., 2014, 'Technology-enhanced learning and teaching in highe education: What is enhanced and how do we know? A critical literature review', Learning, Media and Technology 39(1), 6-36.

LeMarquand, G. \& Galgalo, J.D., 2004, Theological education in contemporary Africa, Eldoret, Nairobi.

Mazur, E., 2012, September, The scientific approach to teaching: Research as a basis for course design, Keynote plenary presentation at the University of Manchester Association for Learning Technology Conference (ALTC), Manchester, UK.

McGloughlin, C. \& Lee, M.J.W., 2010, 'Personalised and self-regulated learning in the Web 2.0 era: International exemplars of innovative pedagogy using social software', Australasian Journal of Educational Technology 26(1), 28-43. https:// doi.org/10.14742/ajet.1100

Mercer, R. \& Simpson, M., 2015, 'What would Kant tweet: The utilisation of online technology in courses involving formation, meaning, and value', Theological Education 49(2), 1-18.

Merriam, S.B., Caffarella, R.S. \& Baumgartner, L.M, 2007, Learning in adulthood: A comprehensive guide, 3rd edn., Jossey-Bass, San Francisco, CA.

Naidoo, M., 2012, 'Approaches to ministerial formation in theological education in South Africa', Theologia Viatorum 36(1), 50-75.

November, A.C., 2010, Empowering students with technology, Corwin, Thousand Oaks, CA

Oliver, E., 2014, 'Theological education with the help of technology', HTS Teologiese Studies/Theological Studies 70(1), 26-43. https://doi.org/10.4102/hts.v70i1.2643

Peterson, A., 2015, 'Big data for faculty development in research and teaching', Theological Education 49(2), 75-88.

Rasha, A.A., 2007, The internet in the Arab world, Egypt and beyond, Peter Lang, New York.

Renwick, S., 2005, 'Knowledge and use of electronic information resources by medical sciences faculty at the University of the West Indies', Journal of the Medical Library Association 93(1), 21-31.

Sajjadi, S.M., 2008, 'Religious education and information technology: Challenges and problems', Teaching Theology and Religion 11(4), 185-190. https://doi. org/10.1111/j.1467-9647.2008.00469.x

Sajjadi, S.M., 2009, 'Is hyper-textual learning a challenge for traditional religious education?', Journal of Contemporary Issues in Education 4(1), 57-70. https://doi. org/10.20355/C53S39

Sajjadi, S.M., 2014, 'Can religious education be rhizomatic?', Middle-East Journal of Scientific Research 19(1), 42-47.

Silvia, W.L. \& Chin-Chung, T., 2011, 'Students' perceptions of collaboration, selfregulated learning, and information seeking in the context of internet-based learning and traditional learning', Computer Human Behaviour 27(2), 905-914. https://doi.org/10.1016/j.chb.2010.11.016

Simpson, M.E., 2014, 'The challenge of theological education in the age of digital learning', Common Ground Journal 11(2), 58-71.

Smith, S.D., Salaway, G. \& Caruso, J.B., 2009, The ECAR study of undergraduate students and information technology, 2009, EDUCAUSE Center for Applied Research (ECAR), viewed 7 July 2016, from https://www.educause.edu/ecar.

Song, L. \& Hill, J.R., 2007, 'A conceptual model for understanding self-directed learning in online environments', Journal of Interactive Online Learning 6(1), 27-42.

Soukup, P.A., 2014, 'Looking at, with, and through Youtube ${ }^{\mathrm{TM}}$ ', Communication Research Trends 33(3), 3-34.

Spadaro, A., 2016, Friending God: Social media, spirituality and community, The Crossroad Publishing Company, New York.

Stuart-Buttle, R., 2013, Virtual theology, faith and adult education: Interruptive pedagogy, Cambridge Scholars, Newcastle upon Tyne.

Stuart-Buttle, R., 2014, 'Interrupting adult learning through online pedagogy', Journal of Education \& Christian Belief 18(1), 61-75. https://doi.org/10.1177/ 205699711401800107

Viktora, J., 2005, 'Not just one more good idea: A reflection on the integration of digital technology in theological education', Theological Education 41(1), $33-44$ 